\title{
Production of Biodiesel Through Transesterification of Crude Palm Oil (CPO) Using Montmorillonite Nanoparticles (Nano-MMT) as Heterogeneous Solid Catalyst
}

\author{
Tisna Harmawan*, Windi Ani, Putri Andani \\ Department of Chemistry, Faculty of Engineering \\ Universitas Samudra \\ Langsa, Indonesia \\ *tisna_harmawan@unsam.ac.id
}

\author{
Teuku Andi Fadlly \\ Department of Physics, Faculty of Engineering \\ Universitas Samudra \\ Langsa, Indonesia
}

\begin{abstract}
Biodiesel is an alternative energy that is environmentally friendly and has properties similar to diesel oil. One source of vegetable oil that can be used as raw material for biodiesel is Crude Palm Oil (CPO). In the CPO, there are various types of fatty acids such as palmitic acid, oleic acid, linoleic acid, stearic acid, and myristic acid. In this research, biodiesel was synthesized through the transesterification reaction of CPO using a heterogeneous solid catalyst Montmorillonite Nanoparticles (Nano-MMT). The transesterification reaction is the reaction of alcohol with triglycerides to form methyl esters (biodiesel) and glycerol with the help of an alkaline catalyst. The method used in this study was to vary the triglyceride: methanol mole ratio (1:6, 1:9, and 1:12). Through the experiment, the optimum yield of biodiesel was 84,9 grams which was obtained under reaction conditions with a catalyst weight of 4 grams, a reaction temperature of $600 \mathrm{C}$, a reaction time of 3 hours and a triglyceride: methanol mole ratio of 1:9. The best biodiesel obtained from the yield is analyzed by Gas ChromatographyMass Spectroscopy (GC-MS). The analysis showed that the biodiesel produced contained $100 \%$ methyl ester and there were several kinds of fatty acids.
\end{abstract}

Keywords-biodiesel, Crude Palm Oil (CPO), montmorillonite nanoparticles, heterogeneous solid catalysis, transesterification reaction

\section{INTRODUCTION}

Currently the use of fuel oil in Indonesia has increased in line with the increasing population and the increasing number of vehicles. Fossil fuels are fuels used today. However, fossil fuels are natural resources that cannot be renewed so that their presence in nature is decreasing due to the increasing demands of energy needs. Solving this problem, it has been found that biodiesel production comes from biological natural sources, namely from Crude Palm Oil (CPO) from palm oil [1].

Indonesia is the second largest CPO producer in the world. This shows that CPO from palm oil has great potential to be used as a raw material for making biodiesel in Indonesia [1].

Biodiesel is a type of biofuel that is both new and renewable [2-6]. Biodiesel (methyl ester) is formed as a result of the reaction between the ester compound (CPO) and the alcohol compound (methanol) to form a new ester compound (methyl ester) [7,8]. Biodiesel synthesis usually often uses liquid catalysts (homogeneous catalysts) yet, but the use of liquid catalysts (acid or alkaline) still has a number of obstacles, namely separating the catalyst from its products is difficult because both are in the liquid phase, corrosive, difficult to handle and store, and the remaining catalyst can no longer be used, resulting in waste that can cause environmental problems. An alternative substitute that needs to be developed is the use of solid catalysts (heterogeneous catalysts) such as Nano-Montmorillonite (Nano-MMT), because solid catalysts have several advantages, including: separation of the product is easier, handling and storage is easier, can be used repeatedly (can regenerated), as well as being more environmentally friendly [9-13].

Nano-MMT is the main content of bentonite $[14,15]$ that has unique properties because it has a very small particle size, resulting in a very high surface area $[2,13]$. Besides, with a very fine size, the characteristic properties of the element will appear and can be engineered like as the properties of magnetism, optics, electricity, thermal, and others, so that their utilization has penetrated various fields of human life, such as health, information, transportation, industry, energy and catalyst [16].

This research used a transesterification reaction, which is the reaction between triglycerides and alcohol to produce methyl esters and glycerol with the help of heterogeneous solid catalyst $[4,7,12,17]$. The alcohol commonly used is methanol. This is because the price of methanol is cheaper and has advantages when viewed from its physical and chemical 
properties, namely it is more polar and the carbon chain is shorter than ethanol $[18,19]$ the reaction shown in Figure 1.

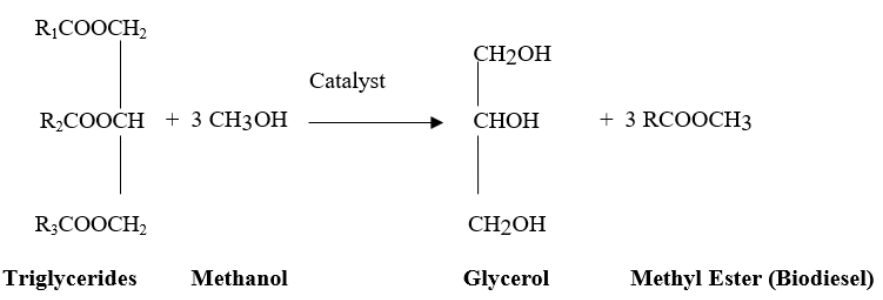

Fig. 1. Transesterification reaction.

A higher reaction rate is obtained at higher temperatures, but a reaction close to the boiling point of methanol has the potential to cause the formation of bubbles which in turn prevents the reaction at the three-phase interface (heterogeneous solid catalyst-oil-alcohol) [18]. From the results of research conducted by Nurhayati et al [1], it shows that the highest biodiesel yield is obtained at a reaction temperature of $60^{\circ} \mathrm{C}$ with a catalyst weight of $4 \%(\mathrm{w} / \mathrm{w})$, because if the amount of catalyst is increased, the number of colliding molecules will increase and the reaction rate will also increase. However, the addition of catalyst weight to $6 \%$ and $8 \%(\mathrm{w} / \mathrm{w})$ did not show an increase in biodiesel yield. The addition of excess catalyst will cause the catalyst to accumulate on the glass reactor walls and will affect the reaction balance, so that at the end of the reaction it will produce more side products.

The reaction time used is 3 hours. It is at this time that the maximum biodiesel is produced. In the initial stage of the transesterification was rapid reaction rate, and then the speed decreases and finally reaches equilibrium in about 3 hours. It can be explained that the transesterification reaction between oil and alcohol is reversible, when the reaction time is long enough. The length of the reaction time depends on the conditions of the oil used. Oils with a large amount of free fatty acids and water require a longer reaction time than oils with small amounts of free fatty acids and water [1].

Research on the transesterification reaction of CPO with temperature, reaction time, and weight of solid catalyst which was still micro-sized in previous research by Nurhayati et al [1] has been carried out. However, the researchers used NanoMMT as heterogeneous solid catalyst using a variation of stoichiometric ratios for the transesterification reaction to produces $100 \%$ biodiesel yield.

\section{MATERIALS AND METHODS}

\section{A. Tools and Materials}

The equipment used were a furnace, sieve, desiccator, porcelain cup, oven, analytical balance, magnetic stirrer hotplate, thermometer, three-neck flask complete with condenser, magnetic stirrer, separating funnel, Whatman 42 filter paper, stopwatch, and equipment other glasses commonly used in laboratories.
The materials used in this study were nanomontmorillonite, CPO, and methanol.

\section{B. Preparation and Characterization of Nano-MMT as Heterogeneous Solid Catalysts}

Synthesis of Nano-MMT material, which is top-down where the synthesis of nano-sized particles directly reduces large materials by grinding with a milling tool, where Montmorillonite is milled with a High Energy Milling (HEM) tool with a milling time of 15 minutes and then characterized with Particles Size Analyzer (PSA).

\section{Biodiesel Production Through Transesterification Reaction with Nano-MMT as a Catalyst Using the Mole Ratio of CPO: Methanol (1: 6, 1: 9, and 1:12)}

- Prepared a three-neck round flask and connected to a condenser (reflux condenser circuit) equipped with a magnetic stirrer and a thermometer.

- Prepared 4 grams of Nano-MMT heterogeneous solid catalyst and $23.82 \mathrm{~g}$ of methanol (1: 6), then mix the two ingredients and stirrer for 10 minutes, and prepared 100 grams of $\mathrm{CPO}\left(50^{\circ} \mathrm{C}\right)$ then put the mixture into a round three neck flask to refluxed for 3 hours at 250 $\mathrm{rpm}$ at temperatures $60^{\circ} \mathrm{C}$.

- Moved the reflux product to a separating funnel and left at room temperature until 2 layers are formed, where the top layer is biodiesel and the bottom layer is glycerol, furthermore separated.

- Washed biodiesel with clean water $\left(55^{\circ} \mathrm{C}\right)$, separated the biodiesel from water, filtered with whatman 42 paper and measure the weight of biodiesel.

- Repetition of treatment was carried out for variations in the mole ratio of CPO: methanol (1: 9 and 1:12) with the same Nano-MMT catalyst weight of 4 grams.

- The biodiesel produced was analyzed using GC-MS.

\section{Biodiesel Analysis Using Gas Cromatography Mass Spectrometry (GC-MS)}

Analysis on biodiesel testing on CPO was carried out using GC-MS which expressed in two parameters, specifically retention time (minutes) and concentration (\%). The retention time is a specific number of interactions between compound molecules in the chromatography column. It is a qualitative indicator of the compound under certain conditions, and the concentration shows the level of purity of the analyzed sample.

\section{RESULTS AND DISCUSSION}

\section{A. Results of Nano-MMT Characterization Using PSA}

Montmorillonite which has been milled for 15 minutes and characterized using PSA produces Nano-MMT with a smallest distribution size of $17.7 \mathrm{~nm}$ as shown in Figure 2. The Nano- 
MMT is then used as heterogeneous solid catalyst in making biodiesel by transesterification of CPO.

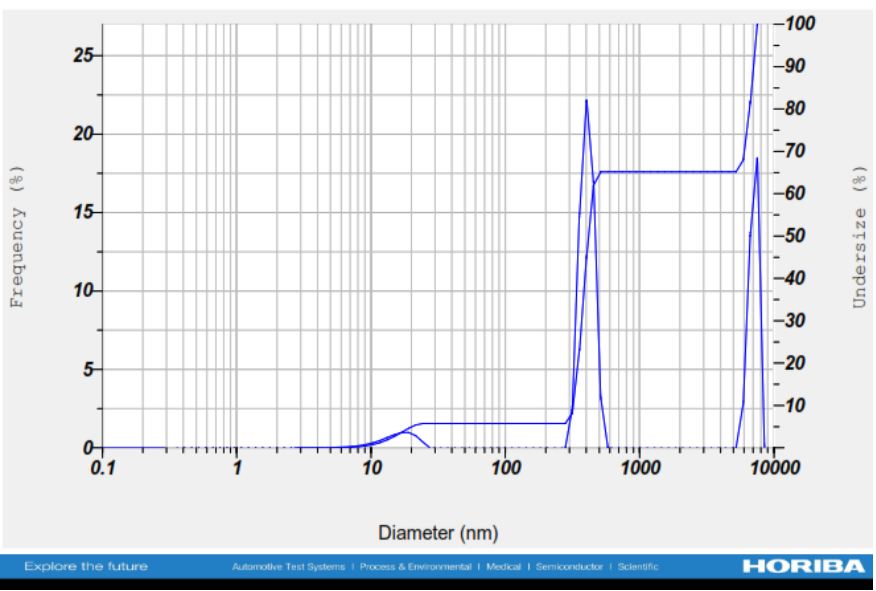

Fig. 2. Montmorillonite Distribution Number chart with 15 minutes milling time.

\section{B. Effect of the molar ratio of CPO: Methanol}

The biodiesel and glycerol formed can be shown in Figure 3 where the top layer is biodiesel and the bottom layer is glycerol. The resulting biodiesel yield as shown in Figure 4 is strongly influenced by the molar ratio of alcohol to triglycerides. The stoichiometric ratio for transesterification requires three moles of alcohol and one mole of triglycerides to produce three moles of fatty acid esters and one mole of glycerol. Transesterification requires a large excess of alcohol to drive the reaction to the right. However, too high molar ratio of alcohol to vegetable oil causes an increase in the solubility of glycerol in the methyl ester layer which makes the separation process difficult [5].

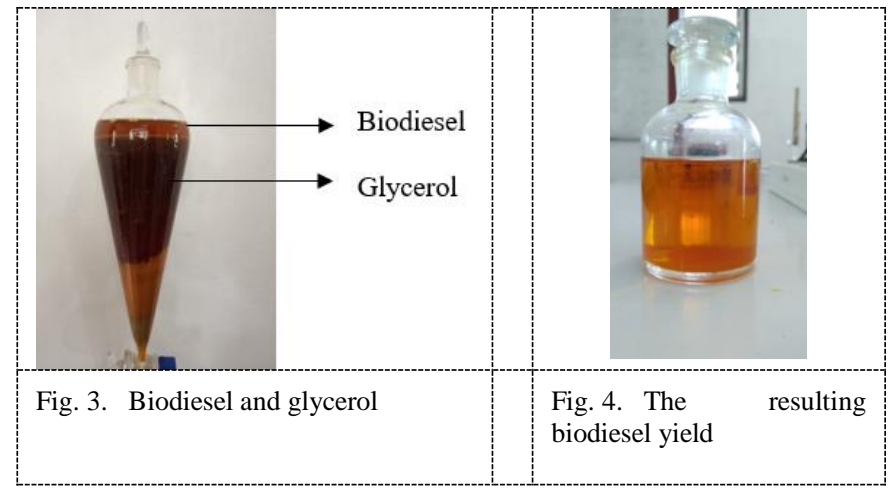

Increasing the mole ratio of CPO: methanol from 1: 6 to 1: 9 increased the yield of biodiesel from $39 \%$ to $84.9 \%$. Furthermore, the molar ratio of CPO: methanol could not increase the yield of biodiesel than before. This is due to the excess or lack of methanol will only result in an increase in the formation of glycerol and emulsion. That means, glycerol will dissolve in excess methanol and then inhibits the methanol reaction in the catalyst reactant, thereby disrupting the separation of glycerol [1]. Furthermore, based on the result of this research the optimum yield of biodiesel was 84,9 grams which was obtained under reaction conditions with a catalyst weight of 4 grams, a reaction temperature of $60^{\circ} \mathrm{C}$, a reaction time of 3 hours and a triglyceride: methanol mole ratio of 1:9 as shown in the Figure 5.

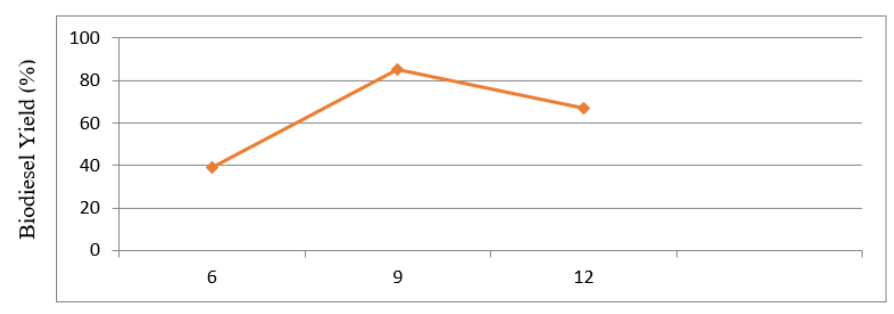

CPO molar ratio: methanol

Fig. 5. Effect of CPO: Methanol molar ratio on biodiesel yield.

\section{Results of Biodiesel Analysis Using GC-MS}

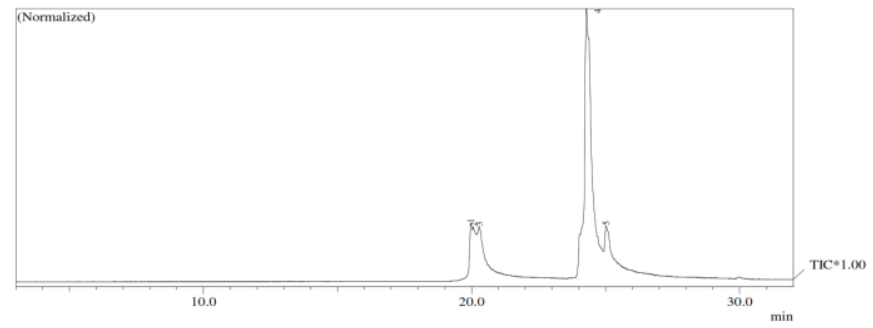

Fig. 6. Peak GC of Biodiesel.

TABLE I. PEAK REPORT TIC OF GAS Chromatography ANALYSIS FOR BIODIESEL PRODUCTS

\begin{tabular}{|c|l|l|l|l|}
\hline Peak & $\begin{array}{c}\text { R.Time } \\
(\mathbf{m i n})\end{array}$ & \multicolumn{1}{|c|}{ Area } & Area (\%) & \multicolumn{1}{|c|}{ Name } \\
\hline 1 & 19.971 & 801186 & 4.73 & $\begin{array}{l}\text { Hexadecanoic acid, methyl ester \$\$ } \\
\text { Palmitic acid, methyl ester \$ } \mathrm{n}- \\
\text { Hexadecanoic acid methyl }\end{array}$ \\
\hline 2 & 20.071 & 997399 & 5.89 & $\begin{array}{l}\text { Hexadecanoic acid, methyl ester } \\
\text { (CAS) Methyl palmitate \$ Methyl } \\
\text { hexadecanoate }\end{array}$ \\
\hline 3 & 20.282 & 1799124 & 10.62 & $\begin{array}{l}\text { Hexadecanoic acid, methyl ester } \\
\text { (CAS) Methyl palmitate \$ Methyl } \\
\text { hexadecanoate }\end{array}$ \\
\hline 4 & 24.281 & 11564050 & 68.23 & $\begin{array}{l}\text { 9-Octadecenoic acid (Z)-, methyl } \\
\text { ester (CAS) Methyl oleate \$\$ Oleic } \\
\text { acid methyl ester }\end{array}$ \\
\hline 5 & 25.017 & 1786380 & 10.54 & $\begin{array}{l}\text { Cyclopentanetridecanoic acid, } \\
\text { methyl ester (CAS) Methyl } \\
\text { dihydrochaulmoograte }\end{array}$ \\
\hline & & 16948139 & 100.00 & \multicolumn{2}{c}{} \\
\hline
\end{tabular}

Based on the result of GC-MS analysis of biodiesel produced five kinds of chromatogram peaks in which there are types of methyl esters which can be seen in the Figure 6. It was showed that the biodiesel produced contained $100 \%$ 
methyl ester and there were several kinds of fatty acids. Furthermore, the fourth peak has the largest percentage area of $68.23 \%$ as shown in the Table $\mathbf{1}$. Where according to SNI 047182-2006 these results have met the quality standard requirements for biodiesel with a minimum ester content of $96.5 \%$.

\section{CONCLUSION}

The results publicized that the optimum biodiesel yield of $100 \mathrm{~g}$ of $\mathrm{CPO}$ is $84.9 \%$ obtained under the following reaction conditions: $4 \%$ catalyst $(\mathrm{w} / \mathrm{w}), 60^{\circ} \mathrm{C}$ reaction temperature, 3 hours reaction time and 1: 9 molar ratio of CPO: methanol. The biodiesel produced in this study has met the SNI 04-7182-2006 biodiesel quality standard which is shown from the GC-MS analysis that the biodiesel product produced has an ester content of $100 \%$.

\section{ACKNOWLEDGMENTS}

We would like to thank Universitas Samudra for Grant of Penelitian Dasar Unggulan (PDU) Scheme and technical supports.

\section{REFERENCES}

[1] Nurhayati., Akmal M., dan Abdul G. 2014. Transesterifikasi Crude Palm Oil (CPO) Menggunakan katalis Heterogen CaO Dari Cangkang Kerang Darah (Anadara Granosa) Kalsinasi 900oC. Ind.Che.Acta. 5 (1) :23-27.

[2] Munir, M., et all. 2020. Production of High Quality Biodiesel from Novel Non-edible Raphnus raphanistrum L. Seed Oil Using Copper Modified Montmorillonite Clay Catalyst. Journal Pre-proof. 1-40.

[3] Sahani, S., Tania R., dan Yogesh C. S. 2019. Clean and Efficient Production of Biodiesel Using Barium Cerate As a Heterogeneous Catalyst for The Biodiesel Production; Kinetics and Thermodynamic Study. Journal of Cleaner Production. 237 : 1-14.

[4] Aghel, B. Majid M. Ahmadreza A. dan Mahmoud M. 2019. Pilot-scale Production of Biodiesel From Waste Cooking Oil Using Kettle Limescale As a Heterogeneous Catalyst. Renewable Energy. 142 : $207-$ 214

[5] Hatrooshi, A. S. A., Valentine C. E., dan Adam P. H. 2019. Production of Biodiesel From Waste Shark Liver Oil For Biofuel Applications. Renewable Energy. 145 : 99-105.
[6] Gujjala, L. K. S., Tapas K. B., dan Rintu B. 2019. Production of Biodiesel Utilizing Laccase Pretreated Lignocellulosic Waste Liquor: An Attempt Towards Cleaner Production Process. Energy Conversion and Management. 196 : 979-987.

[7] Arita, S., Meta B. D., dan Jaya I. 2008. Pembuatan Metil Ester Asam Lemak dari CPO Off Grade denga Metode Esterifikasi-Transesterifikasi. Jurnal Teknik Kimia. 15 (2) : 34-37.

[8] Zaki, M., et all. 2019. Transesterifikasi Minyak Biji Buta-Buta menjadi Biodiesel pada Katalis Heterogen Kalsium Oksida $(\mathrm{CaO})$. Jurnal Rekayasa Kimia dan Lingkungan. 14 (1) : 36-43.

[9] Aziz, M., Dessy A., Isyatun R., dan Stefanus S. C. 2010. Benefiasi Lempung Bogor Untuk Katalis Padat Dalam Sintesis Biodiesel. Jurnal Teknologi Mineral dan Batubara. 6 (2): 75.

[10] Oko, S dan Muhammad F. 2019. Pengembangan Katalis CaO Dengan Cangkang Telur Ayam Dengan Impregnasi $\mathrm{KOH}$ dan Aplikasinya Terhadap Pembuatan Biodiesel Dari Minyak Jarak. Jurnal Teknologi. 11 (2) : 101-110

[11] Yahya, S. dan Farah W. H. 2020. Optimization of Montmorillonite K10 Ion-Exchange With Fe3+ for The Application of Biodiesel Production. Malaysian Jounal of Analytical Sciences. 24 (3) : 390-404.

[12] Rajkumari, K. dan Lalthazuala R. 2020. A Sustainable Protocol for Production of Biodiesel By Transesterification of Soybean Oil Using Banana Trunk Ash As a Heterogeneous Catalyst. Biomass Conversion and Biorefinery.

[13] Dutta, D. K. 2019. Recent Advances In Metal Nanoparticles Supported on Montmorillonite as Catalysts for Organic Synthesis. Journal of Materials Nano Sciences. 6 (1) : 19-31

[14] Wahyuningsih, P., Harmawan, T., dan Halimatussakdiah. 2020. Synthesis and Characterization of Acid-Activated Bentonite from Aceh Tamiang. IOP Conf. Ser.: Mater. Sci. Eng. 725 : 1-5.

[15] Firmansyah, M. 2013. Isolasi dan Karakterisasi Nanopartikel Montmorilonit Dari Bentonit Kabupaten Bener Meriah Skripsi F-MIPA USU Medan.

[16] Harmawan T, Amri Y, Fadlly T. A. 2019. Isolation and Characterization Montmorillonite Nanoparticles of Aceh Tamiang Bentonite as Patchouli Oil Bleaching. Orient J Chem. 35(5), 1535-8.

[17] De, A. dan Siddhartha S. B. 2020. Application of Cu Impregnated TiO2 As a Heterogeneous Nanocatalyst for The Production of Biodiesel From Palm Oil. Fuel. 265 : 1-6.

[18] Sisca, V. 2018. Aplikasi Katalis Padat Dalam Produksi Biodiesel. Jurnal Zarah. 6 (1) : 31-35.

[19] Setyopratomo, P., Edi P., Rudi H., dan J. K. 2008. Pengaruh Suhu Reaksi dan Rasio CPO/Metanol Terhadap Karakteristik Produk Pada Pembuatan Biodiesel Dengan Co-solvent Dietil Eter. Jurnal ILMU DASAR. 9 (1) : 72-77. 